\title{
Secondary analysis of tuberculosis stigma data from a cluster randomised trial in Zambia and South Africa (ZAMSTAR)
}

\author{
V. Bond, ${ }^{* \dagger}$ S. Floyd, ${ }^{\ddagger}$ J. Fenty, ${ }^{\ddagger}$ A. Schaap, ${ }^{\dagger \neq}$ P. Godfrey-Faussett,,$^{\S}$ M. Claassens, ${ }^{\natural}$ K. Shanaube, ${ }^{\dagger}$ \\ H. Ayles, ${ }^{\dagger \S}$ J. R. Hargreaves ${ }^{\#}$ \\ *Department of Global Health and Development, Faculty of Public Health and Policy, London School of Hygiene \& \\ Tropical Medicine, London, UK; 'Zambart, School of Medicine, University of Zambia, Lusaka, Zambia; ${ }^{\ddagger}$ Department \\ of Infectious Diseases Epidemiology, Faculty of Epidemiology and Population Health, ${ }^{\S}$ Department of Clinical \\ Research, Faculty of Infectious and Tropical Diseases, London School of Hygiene \& Tropical Medicine, London, UK; \\ "Desmond Tutu TB Centre, Department of Paediatrics and Child Health, University of Stellenbosch, Tygerberg, \\ South Africa; "Department of Social and Environmental Health Research, Faculty of Public Health and Policy, \\ London School of Hygiene \& Tropical Medicine, UK
}

S U M M ARY

SETTING: Zambian and South African TB and HIV Reduction (ZAMSTAR) cluster-randomised trial (CRT) communities, 2006-2009.

O В JECTIVES: To develop TB stigma items, and evaluate changes in them in response to a household intervention aimed at reducing TB transmission and prevalence but not tailored to reduce stigma.

DESIGN: TB stigma was measured at baseline and 18 months later among 1826 recently diagnosed TB patients and 1235 adult members of their households across 24 communities; 12 of 24 communities were randomised to receive the household intervention. We estimated the impact of the household intervention on TB stigma using standard CRT analytical methods.

RESULTS: Among household members, prevalence of blame and belief in transmission myths fell in both study arms over time: adjusted prevalence ratios (aPRs) comparing the household intervention with the nonhousehold intervention arm were respectively 0.61
(95\%CI $0.26-1.44)$ and $0.77(95 \%$ CI $0.48-1.25)$ at 18-month follow-up. Among TB patients, at baseline a low percentage experienced social exclusion and poor treatment by health staff and a relatively high percentage reported 'being made fun of', with little change over time. Disclosure of TB status increased over time in both study arms. Internalised stigma was less prevalent in the household arm at both baseline and follow-up, with an aPR of 0.85 (95\%CI 0.41-1.76). Variability in stigma levels between countries and across communities was large.

CONCLUSION: Robust TB stigma items were developed. TB stigma was not significantly reduced by the household intervention, although confidence intervals for estimated intervention effects were wide. We suggest that stigma-specific interventions are required to effectively address TB stigma.

KEY WORDS: TB; stigma; CRT; variability
ONE PUBLIC HEALTH APPROACH to reducing disease-related stigma is to improve disease management, which may in turn have the downstream effect of reducing stigma. For example, it has been argued that human immunodeficiency virus (HIV) stigma will be reduced by making HIV treatment widely available. ${ }^{1}$ Through secondary analysis of data from a cluster-randomised trial (CRT) in Zambia and South Africa, this paper asks whether an intervention that was delivered to the households of tuberculosis (TB) patients, aimed at improving patient outcomes and ultimately at reducing $\mathrm{TB}$ transmission and prevalence in the wider community, ${ }^{2}$ also succeeded in reducing $\mathrm{TB}$ stigma.
Stigmatisation of $\mathrm{TB}$ is widely reported in the literature. ${ }^{3-6}$ Key domains of TB stigma include unnecessary fears of transmission, shame, experience of social exclusion, experience of being made fun of, experience of health-setting stigma, internal stigma and disclosure. ${ }^{7-9}$ Despite wide recognition of the issue of TB stigma, there has been relatively little research on the development and application of TB stigma items, or on using such items to evaluate the effect of TB interventions on TB stigma. We used data from a large cohort of TB patient households in Zambia and South Africa to develop indicators for various TB stigma domains, and to evaluate whether

Correspondence to: Virginia Bond, Department of Global Health and Development, Faculty of Public Health and Policy, London School of Hygiene \& Tropical Medicine, Keppel St, Bloomsbury, London WC1E 7HT, UK. e-mail: GBond@ zambart.org.zm

Article submitted 13 December 2016. Final version accepted 5 August 2017. 


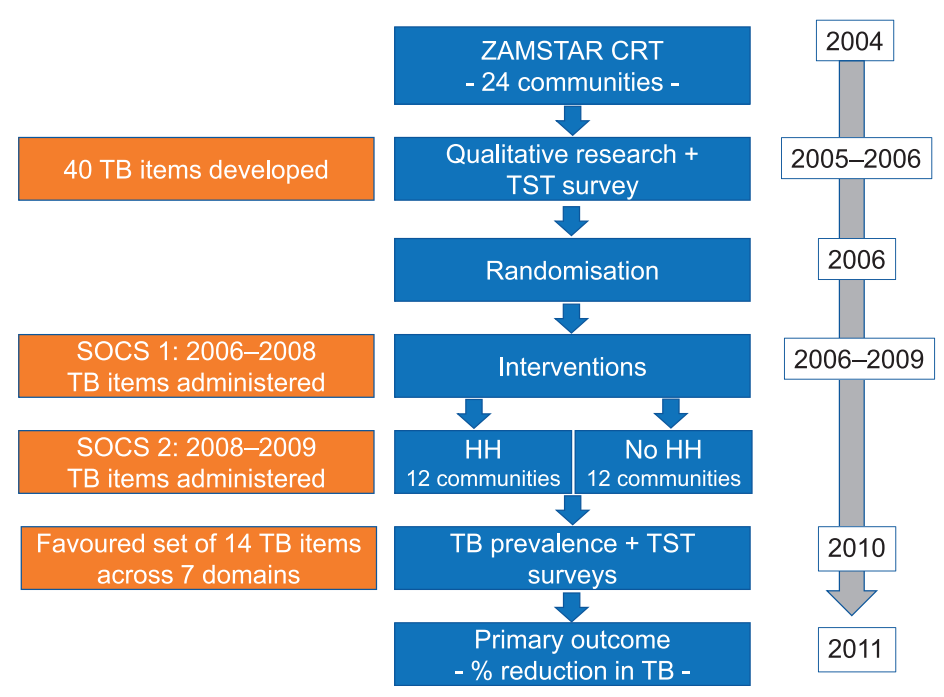

Figure 1 ZAMSTAR CRT and TB stigma item timelines. ZAMSTAR = Zambian and South African TB and HIV Reduction study; CRT = cluster-randomised trial; TB = tuberculosis; TST = tuberculin skin test, SOCS = Secondary Outcome Cohort Study; $\mathrm{HH}=$ household. This image can be viewed online in colour at http://www.ingentaconnect.com/content/iuatld/ijtld/2017/00000021/ a00111s1/art00009

TB stigma was reduced by a household-level TB intervention.

\section{METHODS}

The Zambian and South African TB and HIV Reduction Trial Design

The objective of a CRT (Zambian and South African TB and HIV Reduction study [ZAMSTAR]), carried out from 2004 to 2011 in 24 urban communities (16 in Zambia, 8 in Western Cape, South Africa), was to establish whether it was possible to reduce TB prevalence and incidence at community level using interventions beyond the health services. ${ }^{2}$ Figure 1 summarises the key timelines from the perspective of this analysis in the design, flow and timeline of the wider ZAMSTAR study, thus reflecting the development and administration of TB stigma items in the trial.

At the start of the trial in 2005, baseline research included qualitative enquiry and tuberculin skin test (TST) surveys in all 24 communities. ${ }^{10,11}$ Trial interventions were delivered between 2006 and 2009.2 There were two interventions, household counselling and enhanced case finding (ECF), randomised in a factorial design so that 6 communities were randomised to standard-of-care, 6 to ECF alone, 6 to household counselling alone, and 6 to both ECF and household interventions. ${ }^{2}$ Twelve communities were thus randomised to receive the household-level intervention and 12 did not receive the household intervention. In all communities, delivery of TB services at governmental health facilities and the integration of TB and HIV services were optimised. A TB prevalence survey, and follow-up of the TST survey cohort of schoolchildren, were both conducted in 2010 to measure the effect of the trial interventions. Primary trial findings suggested that the household counselling carried out in TB patient households reduced TB prevalence and transmission at community level. ${ }^{2}$ There was little evidence of any impact of ECF on TB prevalence or transmission. ${ }^{2}$

\section{Household counselling intervention}

The household-level intervention provided TB screening and HIV counselling and testing for all household members. In addition, practical, clinical and emotional support was provided to TB patients and to all adults who were members of their household through visits to the households at least three times during the course of the anti-tuberculosis treatment (see Appendix for further details on the household intervention).* The intervention was not designed with reduction of TB or HIV stigma as a primary aim. However, it was expected that household counsellors would help households manage forms and the consequences of TB and HIV stigma if these were evident during household visits. It was also possible that the household intervention might instigate stigma experiences by increasing the visibility of TB patients, who are often assumed to also have HIV. ${ }^{12}$

\section{Secondary Outcome Cohort Study surveys}

The aim of the Secondary Outcome Cohort Study (SOCS) was to recruit $150 \mathrm{~TB}$-affected households in each of the 24 communities. The sample size was

\footnotetext{
* The appendix is available in the online version of this article, at http://www.ingentaconnect.com/content/iuatld/ijtld/2017/ 00000021/a00111s1/art00009
} 
calculated to be able to measure trial outcomes and to be practical. Households were recruited from among index TB patients initiating anti-tuberculosis treatment at government TB diagnostic health facilities after the start of the trial. TB patients were followed up twice at intervals of approximately 18 months. Three rounds of SOCS and stigma items were thus administered twice to TB patients and their adult household members, in SOCS1 (September 2006August 2008) and in SOCS2 (August 2008-October 2009), with approximately 18 months between interviews. In SOCS2, the items were asked in the same way as at SOCS1 to accommodate any newly diagnosed TB patients. SOCS1 was completed close in time to the TB patient's diagnosis; in communities receiving the household intervention, SOCS1 enrolment was done before the household was offered the intervention. All adults (aged $\geqslant 15$ years) and children $(<5$ years) living in the same household as a TB patient were invited to participate. Participants were asked to respond to a structured questionnaire that included TB and HIV stigma items. Other components of the questionnaire included alcohol use, sexual behaviour, experience of TB and HIV treatment, and (in SOCS2 only) mental health. HIV counselling and rapid HIV testing were offered as a service, and a venous blood sample was collected for laboratory HIV testing.

\section{Development and reduction of tuberculosis stigma indicators}

In 2004-2006, indicators for measuring TB stigma were much less developed than indicators in the HIV field. This made TB stigma items more experimental and unusual. The HIV epidemic had, at the time, swung attention back to health-related stigma. Building on a qualitative multi-country study, ${ }^{13}$ Nyblade et al. pilot-tested HIV stigma indicators in Tanzania. ${ }^{14}$ This pilot has formed the foundation for much HIV stigma measurement subsequently. These HIV stigma indicators drew on the key conceptual domains of stigma. ${ }^{15}$ Drawing on these, and more limited work on TB stigma scales, especially among TB patients, ${ }^{16} \mathrm{VB}$ considered at household level how diagnosed TB patients, PLHIV and other household members might each express and experience stigma. For example, internalised stigma is an essential domain among TB patients and PLHIV, whereas secondary stigma is an essential domain for other household members. VB and JRH followed the mixed-methods approach advocated by Van Brakel ${ }^{17}$ for stigma research, and drew upon earlier qualitative research conducted by Bond in Zambia during 20012007 to provide insights on key TB stigma domains (Appendix Table A.1). Forty items specific to TB stigma, and grouped according to domains, were developed to be administered to TB patients and/or household members.
The items were piloted prior to SOCS1 by trained research assistants in four Zambian communities, in English and three Zambian languages (Nyanja, Bemba and Tonga), and in two South African communities in English, isiXhosa and Afrikaans. All items were translated and back-translated.

Following the administration of the $40 \mathrm{~TB}$ stigma items in SOCS1 and SOCS2, we developed a 'favoured' and 'reduced' set of items. Preliminary analysis of baseline data summarised frequencies and percentages overall and disaggregated according to country, community and sociodemographic characteristics (age, sex, education, rural/urban, language). We then drew again on qualitative data and key literature and held discussions with the trial investigators, statisticians and other social scientists. Translations were also re-reviewed and only items whose meaning was consistently conveyed across different languages were retained for further analysis.

Key literature published since the items were first developed included a TB stigma scale ${ }^{16}$ looking at community and patient perspectives (23 indicators, covering causes, moral values and consequences) and an internalised social stigma scale ${ }^{18}$ adapted from a mental illness scale measuring four dimensions (alienation, perceived discrimination, endorsement of stereotypes and social withdrawal). The latter helped determine which of our items should be retained to address gaps in existing scales. One gap included a paucity of more comprehensive stigma data from TB patients about themselves. For example, Van Rie et al. asked TB patients to recall the experiences of 'other patients', 16 and Macq et al. focused exclusively on internalised stigma experiences of TB patients. ${ }^{18}$

The final selection of a 'favoured set' was determined by the ability of the indicator to: measure both TB and HIV; capture different domains of stigma (casual transmission myths; shame, blame and judgement; enacted stigma; internal stigma; and disclosure); capture responses from both household members and TB patients; measure domains that the interventions might impact; address a gap in the literature; frequencies at baseline; and be consistently translated.

The process of selection and reduction resulted in 14 items across seven pre-specified domains of TB stigma, of which four were asked of household members and 10 of TB patients (Table 1). For the four domains of stigma, we developed indicators drawing on a single binary item (Table 1). For the three remaining domains, which drew on 3 or 4 binary items, we developed a simple summary indicator denoting whether respondents answered affirmatively to at least one of the items. A formal scale development process was not appropriate given the form of the data (yes/no for each item) and the small number of items within each pre-specified domain. 
Table 1 Refined TB stigma indicator set

\begin{tabular}{|c|c|c|c|c|}
\hline Population group & Domain & Items & $\begin{array}{c}\text { Proportion who } \\
\text { responded agree/yes } \\
\%\end{array}$ & Indicator coding* \\
\hline $\begin{array}{l}\text { Household members } \\
\text { of TB patient }\end{array}$ & Transmission myths & $\begin{array}{l}\text { You can catch TB if you touch a patient } \\
\text { who is diagnosed as having TB } \\
\text { You can catch TB by sharing eating utensils } \\
\text { with someone who has TB } \\
\text { You can catch TB from having sex with } \\
\text { someone who has TB }\end{array}$ & $\begin{array}{r}5.8 \\
20.2 \\
24.1\end{array}$ & $\begin{array}{l}1=\text { agrees with one of } \\
\text { these untrue statements } \\
0=\text { disagrees with all }\end{array}$ \\
\hline $\begin{array}{l}\text { Household members } \\
\text { of TB patients }\end{array}$ & Blame & TB is a punishment for bad behaviour & 10.3 & $\begin{array}{l}1=\text { agree } \\
0=\text { disagree }\end{array}$ \\
\hline TB patients & $\begin{array}{l}\text { Experience of social } \\
\text { exclusion }\end{array}$ & $\begin{array}{l}\text { Since you fell sick with TB have you } \\
\text { experienced any of the following: } \\
\text { - Been excluded from a social gathering } \\
\text { - Abandoned by spouse/partner } \\
\text { - Isolated by your household } \\
\text { - Your children or family have been } \\
\text { isolated/shunned }\end{array}$ & $\begin{array}{l}2.8 \\
2.8 \\
2.8 \\
1.5\end{array}$ & $\begin{array}{l}1=\text { answer yes to any one } \\
\text { of these experiences } \\
0=\text { answers no to all }\end{array}$ \\
\hline TB patients & $\begin{array}{l}\text { Experience of being } \\
\text { made fun of }\end{array}$ & $\begin{array}{l}\text { Since you fell sick with TB have you } \\
\text { experienced any of the following: } \\
\text { - Lost respect or standing in the } \\
\text { community } \\
\text { - Been teased, insulted or sworn at } \\
\text { - Been gossiped about }\end{array}$ & $\begin{array}{r}6.4 \\
11.2 \\
18.6\end{array}$ & $\begin{array}{l}1=\text { answer yes to any one } \\
\text { of these experiences } \\
0=\text { answers no to all }\end{array}$ \\
\hline TB patients & $\begin{array}{l}\text { Experience of health- } \\
\text { setting stigma }\end{array}$ & $\begin{array}{l}\text { Since you fell sick with TB have you } \\
\text { experienced any of the following: } \\
\text { - Been treated worse than patients with } \\
\text { other diseases by health staff }\end{array}$ & 1.8 & $\begin{array}{l}1=\text { yes } \\
0=\text { no }\end{array}$ \\
\hline TB patients & Internalised stigma & $\begin{array}{l}\text { Since you were diagnosed with TB have } \\
\text { you felt: } \\
\text { - Unclean or dirty because of your TB }\end{array}$ & 8.7 & $\begin{array}{l}1=\text { yes } \\
0=\text { no }\end{array}$ \\
\hline TB patients & Disclosure & $\begin{array}{l}\text { Have you told anyone outside of your } \\
\text { household about your TB diagnosis? }\end{array}$ & 72.3 & $\begin{array}{l}1=\text { yes } \\
0=\text { no }\end{array}$ \\
\hline
\end{tabular}

* Answers indicative of stigma were coded ' 1 ' and answers indicative of no stigma were coded ' 0 '.

$\mathrm{TB}=$ tuberculosis.

\section{Data collection}

Once written informed consent had been obtained, the research questionnaire was administered using paper copies by research assistants paired with a nurse/counsellor. Often, but not always, respondents were interviewed by the same pair at SOCS1 and SOCS2. The questionnaires took around $40 \mathrm{~min}$ on average to administer.

\section{Ethics}

Ethics clearance was obtained from the Biomedical Ethics Committee at the University of Zambia, Lusaka, Zambia; the Stellenbosch Health Research Ethics Committee, Tygerberg, South Africa; and the London School of Hygiene \& Tropical Medicine
Ethics Committee, London, UK. Governmental approval for the trial was obtained in both countries.

\section{Study and analysis population}

The study population was all adult TB patients and adult members of their households (with no TB) who consented to participate in SOCS1. The analysis population for measuring the effect of the household intervention on stigma outcomes was the population that was retained at SOCS2 (Table 2).

\section{Analysis}

For each of the seven stigma domains, we summarised their prevalence at SOCS1, at SOCS1 with restriction to adults who were followed up at SOCS2, and at

Table 2 sOCS study cohorts at baseline and follow-up

\begin{tabular}{|c|c|c|c|c|}
\hline & \multicolumn{2}{|c|}{ TB patients } & \multicolumn{2}{|c|}{ Household members of TB patients } \\
\hline & $\begin{array}{c}\text { Household counselling } \\
n\end{array}$ & $\begin{array}{c}\text { No household counselling } \\
n\end{array}$ & $\begin{array}{c}\text { Household counselling } \\
n\end{array}$ & $\begin{array}{c}\text { No household counselling } \\
n\end{array}$ \\
\hline Baseline & 2434 & 2193 & 2501 & 2321 \\
\hline Excluded from follow-up analysis* & 1501 & 1300 & 1294 & 1212 \\
\hline Incident $\mathrm{TB}^{+}$ & NA & NA & 40 & 39 \\
\hline Analysis population at follow-up & 933 (38\% of cohort) & 893 (40\% of cohort) & 1167 (45\% of cohort) & 1068 (44\% of cohort) \\
\hline
\end{tabular}

* Individuals with no follow-up, unknown TB status, missing data.

${ }^{+}$Individuals with incident TB were also excluded from the analysis population at follow-up.

SOCS $=$ Secondary Outcome Cohort Study; TB = tuberculosis; NA = not available. 
SOCS2, both overall and separately for Zambia and South Africa.

Our main analysis was aimed at comparing the 12 communities that were randomised to receive the household intervention with the 12 that were not for stigma prevalence at the time of SOCS2. We present both unadjusted and adjusted analyses, with adjusted analysis using a two-stage approach that is standard for a community-randomised trial with $<30$ communities. $^{2}$

For each stigma indicator, the proportion (prevalence) of each stigma indicator was calculated separately for each community in the unadjusted analysis; a log transformation was then applied to reduce the skewness of the distributions. To compare communities, the geometric mean of the proportions was calculated for the 12 communities with the household intervention, and the 12 communities without the intervention. The effect of the intervention was measured by a prevalence ratio (PR), equal to the ratio of the two geometric means.

With regard to the primary endpoint of the trial, the adjusted analysis was performed in two stages. ${ }^{4}$ The first stage was to fit a logistic regression model to individual-level data, separately for Zambian and Western Cape communities, adjusting for community, household and individual characteristics as prespecified in the trial statistical analysis plan. The logistic regression model was used to predict the expected number (E) of adults with the stigma outcome, under the null hypothesis of no household intervention effect. The ratio of observed $(\mathrm{O})$ to expected (E) events $(\mathrm{O} / \mathrm{E})$ was calculated for each community, the geometric mean of $\mathrm{O} / \mathrm{E}$ was calculated separately for communities with and without the household intervention, and PRs for the household intervention effect were calculated as the ratio of geometric means.

\section{RESULTS}

\section{Study population}

The study population comprised 1826 TB patients and 1235 adult members of their households. At baseline, the distribution of age, sex, education and marital status was similar in household intervention and non-household intervention communities among both household members and TB patients (Table 3), whereas household wealth was lower in household communities. There was a higher proportion of men among TB patients and a higher proportion of women among household members, and a higher proportion of TB patients in the 25-49 year age range compared with those who were not TB patients. The percentage of adults who were HIV-positive was high among both household members and TB patients, at around $30 \%$ and $65 \%$, respectively. The sociodemographic profile of adults followed up at SOCS2 was overall similar to the profile of all adults enrolled at SOCS1, with a slight shift towards more women and fewer younger adults.

\section{Household-level tuberculosis stigma: transmission myths and blaming patterns among household members}

Agreement with 'fear and myths' and with 'blame' was higher in Zambia than in South Africa at baseline, and in both countries it was lower in the household than the non-household arm. Restricting our analysis to adults who were followed up, findings at baseline were similar to those in the total study population (Table 4).

At follow-up, agreement with 'fear and myths' and with 'blame' was overall lower than at baseline, in both Zambia and South Africa and in both household and non-household communities (Table 4). At both baseline and follow-up, there was substantial between-community variation, particularly in Zambia (Figure 2).

Table 5 summarises the unadjusted and adjusted analyses of whether the household intervention reduced stigma. For 'fear and myths', the geometric mean value of household intervention communities was $13.2 \%$, and this was $27.6 \%$ for non-household intervention communities, with an unadjusted PR of 0.48 (95\% confidence interval [CI] $0.16-1.38)$. The association was weakened after adjustment, with a PR of 0.61. There was no statistical evidence that the household intervention reduced belief in transmission myths or blaming patterns, but the CIs were wide and for both outcomes the PR was $<1$ (Figure 1, Appendix Table A.2).

\section{Tuberculosis patients' experiences of stigma}

At baseline, 'being made fun of' was the most common form of stigma reported by $\mathrm{TB}$ patients (Table 4), more common in Zambia than in South Africa. The prevalence of internalised stigma was higher in the non-household than in the household communities in both countries. Over half of TB patients had told someone outside of their household about their TB diagnosis, except for TB patients in South African household communities, where the prevalence of disclosure was $35 \%$. There were large variations across communities in the prevalence of being made fun of, internalised stigma and disclosure of TB status. The prevalence of social exclusion was relatively low, and there were few reports of healthsetting stigma.

In Zambia, the prevalence of 'being made fun of' was lower at follow-up than at baseline in the household communities, and higher in the nonhousehold communities, with opposite findings in South Africa (Table 4). Once adjusted, there was little statistical evidence that the household intervention reduced the prevalence of this outcome (adjusted PR 
Table 3 Sociodemographic characteristics of the study population at baseline and follow-up

\begin{tabular}{|c|c|c|c|c|c|c|c|c|}
\hline & \multicolumn{4}{|c|}{ Baseline } & \multicolumn{4}{|c|}{ Follow-up } \\
\hline & \multicolumn{2}{|c|}{ Household member } & \multicolumn{2}{|c|}{ TB patient } & \multicolumn{2}{|c|}{ Household member } & \multicolumn{2}{|c|}{ TB patient } \\
\hline & $\begin{array}{c}\text { Household } \\
n(\%)\end{array}$ & $\begin{array}{c}\text { Non-household } \\
n(\%)\end{array}$ & $\begin{array}{l}\text { Household } \\
n(\%)\end{array}$ & $\begin{array}{c}\text { Non-household } \\
n(\%)\end{array}$ & $\begin{array}{c}\text { Household } \\
n(\%)\end{array}$ & $\begin{array}{c}\text { Non-household } \\
n(\%)\end{array}$ & $\begin{array}{c}\text { Household } \\
n(\%)\end{array}$ & $\begin{array}{c}\text { Non-household } \\
n(\%)\end{array}$ \\
\hline$n$ & 2501 & 2321 & 2434 & 2193 & 1175 & 1069 & 935 & 896 \\
\hline $\begin{array}{l}\text { Sex } \\
\text { Male } \\
\text { Female } \\
\text { Unknown }\end{array}$ & $\begin{array}{c}788(31.5) \\
1713(68.5) \\
0\end{array}$ & $\begin{array}{c}705(30.4) \\
1616(69.6) \\
0\end{array}$ & $\begin{array}{c}1320(54.2) \\
1113(45.7) \\
1(0)\end{array}$ & $\begin{array}{c}1125(51.3) \\
1068(48.7) \\
0\end{array}$ & $\begin{array}{c}317(27) \\
858(73) \\
0\end{array}$ & $\begin{array}{c}294(27.5) \\
775(72.5) \\
0\end{array}$ & $\begin{array}{c}470(50.3) \\
465(49.7) \\
0\end{array}$ & $\begin{array}{c}435(48.5) \\
461(51.5) \\
0\end{array}$ \\
\hline $\begin{array}{l}\text { HIV status } \\
\text { HIV-negative } \\
\text { HIV-positive } \\
\text { Indeterminate/unknown }\end{array}$ & $\begin{array}{l}1710(68.4) \\
679(27.1) \\
112(4.5)\end{array}$ & $\begin{array}{c}1556(67) \\
660(28.4) \\
105(4.5)\end{array}$ & $\begin{array}{c}741(30.4) \\
1562(64.2) \\
131(5.4)\end{array}$ & $\begin{array}{c}627(28.6) \\
1463(66.7) \\
103(4.7)\end{array}$ & $\begin{array}{l}802(68.3) \\
353(30) \\
20(1.7)\end{array}$ & $\begin{array}{l}727(68) \\
319(29.8) \\
23(2.2)\end{array}$ & $\begin{array}{c}273(29.2) \\
657(70.3) \\
5(0.5)\end{array}$ & $\begin{array}{l}248(27.7) \\
639(71.3) \\
9(1.0)\end{array}$ \\
\hline $\begin{array}{l}\text { Age group, years } \\
\begin{array}{l}15-24 \\
25-29 \\
30-34 \\
35-39 \\
40-49 \\
\geqslant 50 \\
\text { Unknown }\end{array}\end{array}$ & $\begin{array}{l}932(37.3) \\
327(13.1) \\
277(11.1) \\
195(7.8) \\
316(12.6) \\
437(17.5) \\
17(0.7)\end{array}$ & $\begin{array}{c}923(39.8) \\
315(13.6) \\
242(10.4) \\
178(7.7) \\
262(11.3) \\
392(16.9) \\
9(0.4)\end{array}$ & $\begin{array}{l}435(17.9) \\
449(18.4) \\
523(21.5) \\
400(16.4) \\
400(16.4) \\
216(8.9) \\
11(0.5)\end{array}$ & $\begin{array}{l}384(17.5) \\
390(17.8) \\
455(20.7) \\
366(16.7) \\
358(16.3) \\
229(10.4) \\
11(0.5)\end{array}$ & $\begin{array}{c}353(30) \\
159(13.5) \\
121(10.3) \\
111(9.4) \\
169(14.4) \\
260(22.1) \\
2(0.2)\end{array}$ & $\begin{array}{c}351(32.8) \\
150(14) \\
116(10.9) \\
103(9.6) \\
120(11.2) \\
229(21.4) \\
0\end{array}$ & $\begin{array}{l}113(12.1) \\
157(16.8) \\
197(21.1) \\
166(17.8) \\
187(20) \\
114(12.2) \\
1(0.1)\end{array}$ & $\begin{array}{l}104(11.6) \\
156(17.4) \\
167(18.6) \\
163(18.2) \\
181(20.2) \\
124(13.8) \\
1(0.1)\end{array}$ \\
\hline $\begin{array}{l}\text { Highest school grade att } \\
\text { None/grade 1-2 } \\
\text { Grade 3-6 } \\
\text { Grade } 7-10 \\
\text { Grade 11-12 } \\
\text { College/university } \\
\text { Unknown }\end{array}$ & $\begin{array}{l}\text { nded } \\
258(10.3) \\
416(16.6) \\
1274(50.9) \\
435(17.4) \\
102(4.1) \\
16(0.6)\end{array}$ & $\begin{array}{c}208(9) \\
326(14) \\
1147(49.4) \\
468(20.2) \\
159(6.9) \\
13(0.6)\end{array}$ & $\begin{array}{c}213(8.8) \\
446(18.3) \\
1249(51.3) \\
387(15.9) \\
130(5.3) \\
9(0.4)\end{array}$ & $\begin{array}{c}175(8) \\
362(16.5) \\
1105(50.4) \\
397(18.1) \\
141(6.4) \\
13(0.6)\end{array}$ & $\begin{array}{c}128(10.9) \\
192(16.3) \\
632(53.8) \\
182(15.5) \\
41(3.5) \\
0\end{array}$ & $\begin{array}{c}104(9.7) \\
145(13.6) \\
534(50) \\
200(18.7) \\
86(8) \\
0\end{array}$ & $\begin{array}{c}79(8.4) \\
182(19.5) \\
468(50.1) \\
148(15.8) \\
58(6.2) \\
0\end{array}$ & $\begin{array}{c}67(7.5) \\
138(15.4) \\
485(54.1) \\
137(15.3) \\
69(7.7) \\
0\end{array}$ \\
\hline $\begin{array}{l}\text { Marital status } \\
\text { Single } \\
\text { Married } \\
\text { Widowed } \\
\text { Separated } \\
\text { Unknown }\end{array}$ & $\begin{array}{c}1103(44.1) \\
1111(44.4) \\
171(6.8) \\
110(4.4) \\
6(0.2)\end{array}$ & $\begin{array}{c}999(43) \\
1029(44.3) \\
178(7.7) \\
113(4.9) \\
2(0.1)\end{array}$ & $\begin{array}{c}971(39.9) \\
1031(42.4) \\
169(6.9) \\
257(10.6) \\
6(0.2)\end{array}$ & $\begin{array}{c}909(41.5) \\
859(39.2) \\
195(8.9) \\
230(10.5) \\
0\end{array}$ & $\begin{array}{c}475(40.4) \\
529(45) \\
128(10.9) \\
41(3.5) \\
2(0.2)\end{array}$ & $\begin{array}{c}428(40) \\
463(43.3) \\
127(11.9) \\
49(4.6) \\
2(0.2)\end{array}$ & $\begin{array}{c}350(37.4) \\
444(47.5) \\
80(8.6) \\
60(6.4) \\
1(0.1)\end{array}$ & $\begin{array}{c}369(41.2) \\
373(41.6) \\
81(9) \\
71(7.9) \\
2(0.2)\end{array}$ \\
\hline $\begin{array}{l}\text { Household wealth index* } \\
\text { Poorest } \\
2^{\text {nd }} \text { quartile } \\
3^{\text {rd }} \text { quartile } \\
\text { Wealthiest } \\
\text { Unknown }\end{array}$ & $\begin{array}{c}551(22) \\
880(35.2) \\
481(19.2) \\
547(21.9) \\
42(1.7)\end{array}$ & $\begin{array}{c}244(10.5) \\
443(19.1) \\
671(28.9) \\
926(39.9) \\
37(1.6)\end{array}$ & $\begin{array}{c}594(24.4) \\
866(35.6) \\
479(19.7) \\
449(18.4) \\
46(1.9)\end{array}$ & $\begin{array}{c}338(15.4) \\
481(21.9) \\
651(29.7) \\
702(32) \\
21(1)\end{array}$ & $\begin{array}{c}265(22.6) \\
403(34.3) \\
216(18.4) \\
291(24.8) \\
0\end{array}$ & $\begin{array}{c}109(10.2) \\
172(16.1) \\
302(28.3) \\
486(45.5) \\
0\end{array}$ & $\begin{array}{c}211(22.6) \\
312(33.4) \\
217(23.2) \\
195(20.9) \\
0\end{array}$ & $\begin{array}{c}126(14.1) \\
204(22.8) \\
282(31.5) \\
284(31.7) \\
0\end{array}$ \\
\hline
\end{tabular}

* Calculated using the first principal component of a principal components analysis including: does the household own a radio, television, fridge, bicycle, motorbike, or car; does the household have a non-family domestic worker; type of water source; type of toilet facilities; type of flooring; does the household own a digital video disc (DVD) player (South Africa only).

$\mathrm{TB}=$ tuberculosis; $\mathrm{HIV}=$ human immunodeficiency virus

$=0.89$, Table 5). The prevalence of social exclusion and experience of health-setting stigma changed little between baseline and follow-up (Table 5). The prevalence of disclosure of $\mathrm{TB}$ status increased in household and non-household communities in both Zambia and South Africa.

The prevalence of internalised stigma fell in the household communities in both Zambia and South Africa, and also in the non-household communities in South Africa, but increased in the non-household communities in Zambia (aPR 0.85 , but with wide 95\% CIs) (Figure 1).

\section{DISCUSSION}

This CRT provided a rare opportunity to develop, apply, refine and assess a TB item set within a CRT to measure the impact of an intervention. Fourteen items across seven TB stigma domains included longitudinal perspectives of both household members $(n=1253)$ and TB patients $(n=1826)$. Qualitative data helped develop the indicators. Our objectives were to develop TB stigma items and to measure if a household intervention that was not designed with stigma reduction as a core aim, but which was successful in improving TB management and reducing $\mathrm{TB}$ prevalence, may also reduce $\mathrm{TB}$ stigma. Overall, we found little evidence that the forms of stigma we measured were reduced by the household intervention. Some, but not all, types of stigma were reduced over time in both arms of the trial.

The large between-community variation in reported TB stigma limited our ability to show an effect of the household intervention on TB stigma; however, it did highlight the powerful influence of context at both community and country levels. The 
Table 4 Prevalence of A) household member and B) TB patient TB stigma at baseline and follow-up* A)

\begin{tabular}{|c|c|c|c|c|c|c|}
\hline & \multicolumn{2}{|c|}{ Zambia } & \multicolumn{2}{|c|}{ South Africa } & \multicolumn{2}{|c|}{ Overall } \\
\hline & $\begin{array}{c}\text { Household } \\
n(\%)\end{array}$ & $\begin{array}{c}\text { Non-household } \\
n(\%)\end{array}$ & $\begin{array}{c}\text { Household } \\
n(\%)\end{array}$ & $\begin{array}{c}\text { Non-household } \\
n(\%)\end{array}$ & $\begin{array}{c}\text { Household } \\
n(\%)\end{array}$ & $\begin{array}{c}\text { Non-household } \\
n(\%)\end{array}$ \\
\hline \multicolumn{7}{|l|}{ Baseline } \\
\hline Household members, $n$ & 1463 & 1596 & 1038 & 725 & 2501 & 2321 \\
\hline Fears and myths & $715(48.9)$ & $941(59)$ & $215(20.7)$ & $229(31.6)$ & $930(37.2)$ & $1170(50.4)$ \\
\hline Blame & $200(13.7)$ & $323(20.2)$ & $51(4.9)$ & $124(17.1)$ & $251(10)$ & $447(19.3)$ \\
\hline \multicolumn{7}{|l|}{ Baseline $^{+}$} \\
\hline Household members, $n$ & 718 & 834 & 457 & 235 & 1175 & 1069 \\
\hline Fears and myths & $348(48.5)$ & $486(58.3)$ & 89 (19.5) & $73(31.1)$ & $437(37.2)$ & $559(52.3)$ \\
\hline Blame & $96(13.4)$ & $176(21.1)$ & $21(4.6)$ & $40(17)$ & $117(10)$ & $216(20.2)$ \\
\hline \multicolumn{7}{|l|}{ Follow-up } \\
\hline Individuals included in analysis at follow-up, $n$ & 718 & 834 & 457 & 235 & 1175 & 1069 \\
\hline Fears and myths & $205(28.6)$ & $385(46.2)$ & $74(16.2)$ & $53(22.6)$ & $279(23.7)$ & $438(41)$ \\
\hline Blame & $51(7.1)$ & $153(18.3)$ & $9(2)$ & $19(8.1)$ & $60(5.1)$ & $172(16.1)$ \\
\hline
\end{tabular}

B)

\begin{tabular}{|c|c|c|c|c|c|c|}
\hline & \multicolumn{2}{|c|}{ Zambia } & \multicolumn{2}{|c|}{ South Africa } & \multicolumn{2}{|c|}{ Overall } \\
\hline & $\begin{array}{c}\text { Household } \\
n(\%)\end{array}$ & $\begin{array}{c}\text { Non-household } \\
n(\%)\end{array}$ & $\begin{array}{c}\text { Household } \\
n(\%)\end{array}$ & $\begin{array}{c}\text { Non-household } \\
n(\%)\end{array}$ & $\begin{array}{c}\text { Household } \\
n(\%)\end{array}$ & $\begin{array}{c}\text { Non-household } \\
n(\%)\end{array}$ \\
\hline \multicolumn{7}{|l|}{ Baseline } \\
\hline TB patients, $n$ & 1550 & 1205 & 884 & 988 & 2434 & 2193 \\
\hline Experience of social exclusion & $101(6.5)$ & $116(9.6)$ & $20(2.3)$ & $46(4.7)$ & $121(5)$ & $162(7.4)$ \\
\hline Experience of being made fun of & $433(27.9)$ & $307(25.5)$ & $23(2.6)$ & $85(8.6)$ & $456(18.7)$ & 392 (17.9) \\
\hline Experience of health-setting stigma & $14(0.9)$ & $36(3)$ & $4(0.5)$ & $14(1.4)$ & $18(0.7)$ & $50(2.3)$ \\
\hline Internalised stigma & $61(3.9)$ & $179(14.9)$ & $37(4.2)$ & $178(18)$ & $98(4)$ & $357(16.3)$ \\
\hline Disclosure & $876(56.5)$ & $744(61.7)$ & $292(33)$ & $672(68)$ & $1168(48)$ & $1416(64.6)$ \\
\hline \multicolumn{7}{|l|}{ Baseline $^{\dagger}$} \\
\hline TB patients, $n$ & 636 & 574 & 299 & 322 & 935 & 896 \\
\hline Experience of social exclusion & $44(6.9)$ & $46(8)$ & $7(2.3)$ & $22(6.8)$ & $51(5.5)$ & $68(7.6)$ \\
\hline Experience of being made fun of & $208(32.7)$ & $135(23.5)$ & $9(3)$ & $36(11.2)$ & $217(23.2)$ & $171(19.1)$ \\
\hline Experience of health-setting stigma & $5(.8)$ & $19(3.3)$ & $0(0)$ & $5(1.6)$ & $5(.5)$ & $24(2.7)$ \\
\hline Internalised stigma & $21(3.3)$ & $75(13.1)$ & $15(5)$ & $57(17.7)$ & $36(3.9)$ & $132(14.7)$ \\
\hline Disclosure & $383(60.2)$ & $374(65.2)$ & $105(35.1)$ & $216(67.1)$ & $488(52.2)$ & $590(65.8)$ \\
\hline \multicolumn{7}{|l|}{ Follow-up } \\
\hline Included in analysis at follow-up, $n$ & 636 & 574 & 299 & 322 & 935 & 896 \\
\hline Experience of social exclusion & $47(7.4)$ & $65(11.3)$ & $9(3)$ & $9(2.8)$ & $56(6)$ & $74(8.3)$ \\
\hline Experience of being made fun of & $157(24.7)$ & $187(32.6)$ & $17(5.7)$ & $16(5)$ & $174(18.6)$ & $203(22.7)$ \\
\hline Experience of health-setting stigma & $3(0.5)$ & $20(3.5)$ & $5(1.7)$ & $5(1.6)$ & $8(.9)$ & $25(2.8)$ \\
\hline Internalised stigma & $17(2.7)$ & $102(17.8)$ & $4(1.3)$ & $37(11.5)$ & $21(2.2)$ & $139(15.5)$ \\
\hline Disclosure & $478(75.2)$ & $437(76.1)$ & $157(52.5)$ & $251(78)$ & $635(67.9)$ & $688(76.8)$ \\
\hline
\end{tabular}

* The prevalence values reported for each outcome were calculated by first calculating the prevalence at SOCS2 in each of the 24 communities, and then calculating the geometric mean of the 12 values for the communities that received the household intervention and the 12 values for the communities that did not receive the intervention.

${ }^{+}$Prevalence of indicators at baseline, with restriction to individuals who were followed up at SOCS2. These values are shown to ascertain whether the prevalence of reported stigma was similar among those who were followed up at SOCS2 compared with all who were enrolled in the study.

TB = tuberculosis; SOCS = Secondary Outcome Cohort Study.

prevalence of the two stigma domains (transmission myths and blame) that we measured among household members of TB patients declined over time in both arms and in both countries, and in most communities. Fear of being infected with TB is a key cause of TB stigma. ${ }^{19-21}$ This may indicate that households that participated in the study became more aware of TB issues over time, or that the study had been undertaken at a time of changing overall trends in TB stigma. Another possibility is that a 'Hawthorne effect' meant that participation in the SOCS research reduced this form of stigma and that there was no additional effect from the household intervention. Holding TB patients culpable for their infection is another key cause of TB stigma. ${ }^{12,22}$ In
South Africa, a history of being familiar with prevalent $\mathrm{TB}$ combined with the potential of household counsellors to discourage blame could have influenced the more subdued culpability. ${ }^{23}$

Among TB patients, all three indicators of stigma experienced were well balanced at baseline and changed little over time; also, there was little evidence of an impact of the household intervention. These three indicators of TB stigma experienced among TB patients are particularly valuable because this type of evidence is unusual. Other scales have focused more on TB patient experiences of internalised stigma, ${ }^{18}$ experiences of 'other' TB patients, ${ }^{16,24}$ fears of transmission and shame ${ }^{12}$ and health facility stigma. ${ }^{22}$ A multi-country study in Bangladesh, India, 


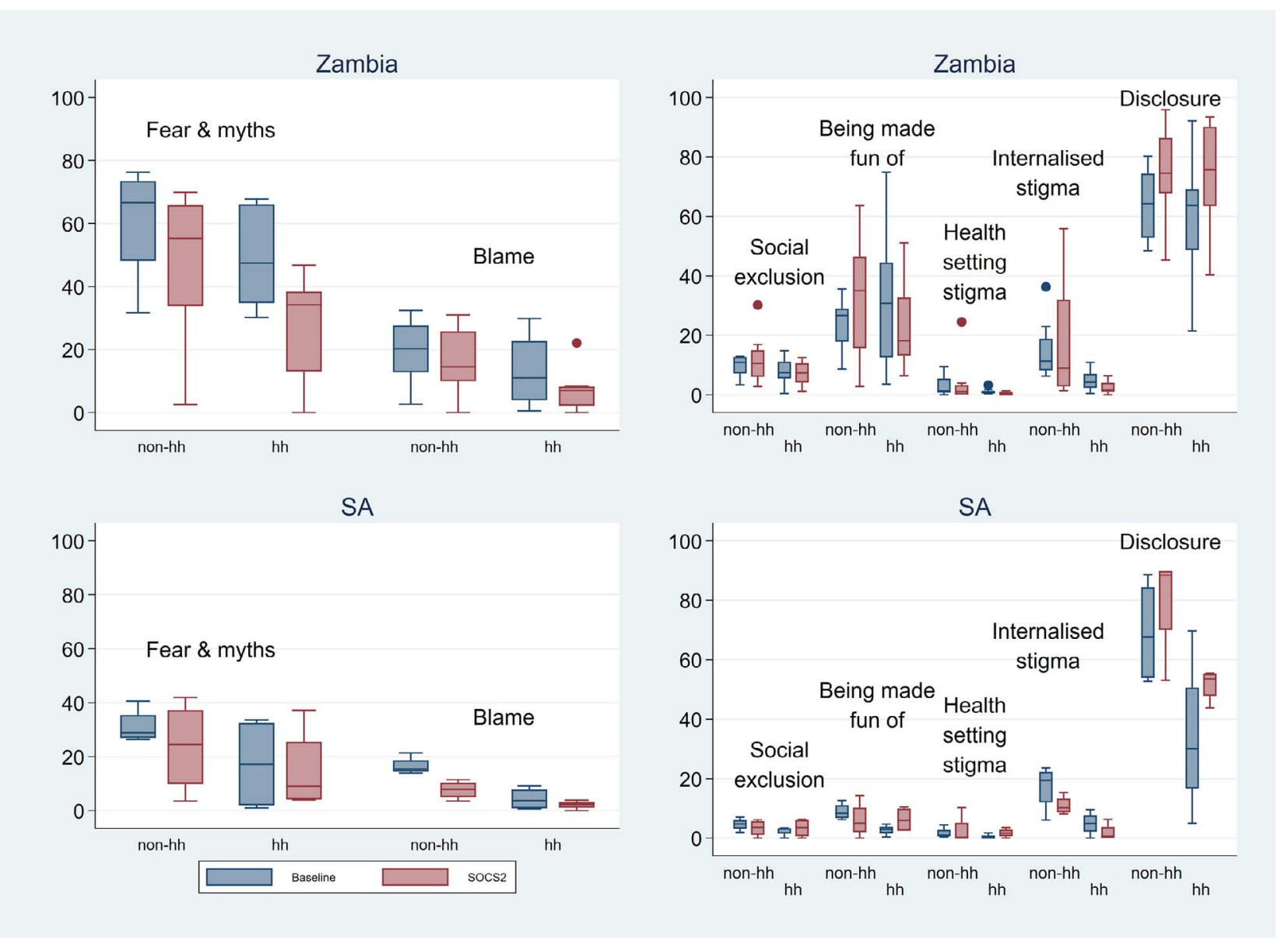

Figure 2 Community level variation in household member TB stigma. TB = tuberculosis; SOCS=Secondary Outcome Cohort Study. This image can be viewed online in colour at http://www.ingentaconnect.com/content/iuatld/ijtld/2017/00000021/a00111s1/ art00009

Table 5 Stigma levels among household members and TB patients at SOCS2

\begin{tabular}{|c|c|c|c|c|c|c|}
\hline \multirow[b]{2}{*}{ Indicators } & \multirow[b]{2}{*}{ Intervention } & \multicolumn{3}{|c|}{ Unadjusted } & \multicolumn{2}{|c|}{ Adjusted* } \\
\hline & & $\begin{array}{l}\text { Geometric mean } \\
\text { prevalence }\end{array}$ & PR $(95 \% \mathrm{Cl})$ & $P$ value & PR $(95 \% \mathrm{Cl})$ & $P$ value \\
\hline \multicolumn{7}{|l|}{ Household members } \\
\hline \multirow[t]{2}{*}{ Fears and myths } & Non-household & 27.6 & - & - & - & - \\
\hline & Household & 13.2 & $0.48(0.16-1.38)$ & 0.159 & $0.61(0.26-1.44)$ & 0.237 \\
\hline \multirow[t]{2}{*}{ Blame } & Non-household & 9.9 & - & - & - & - \\
\hline & Household & 3.8 & $0.38(0.16-0.93)$ & 0.036 & $0.77(0.48-1.25)$ & 0.276 \\
\hline \multicolumn{7}{|l|}{ TB patients } \\
\hline \multirow[t]{2}{*}{ Social exclusion } & Non-household & 6.4 & - & - & - & - \\
\hline & Household & 4.5 & $0.71(0.33-1.50)$ & 0.347 & $0.78(0.45-1.35)$ & 0.350 \\
\hline \multirow{2}{*}{ Being made fun of } & Non-household & 13.1 & - & - & - & - \\
\hline & Household & 12.1 & $0.92(0.39-2.17)$ & 0.846 & $0.89(0.45-1.75)$ & 0.713 \\
\hline \multirow[t]{2}{*}{ Health-setting stigma } & Non-household & 2.4 & - & - & - & - \\
\hline & Household & 1.5 & $0.61(0.31-1.22)$ & 0.151 & $0.61(0.31-1.20)$ & 0.143 \\
\hline \multirow[t]{2}{*}{ Internalised stigma } & Non-household & 9.5 & - & - & - & - \\
\hline & Household & 2.1 & $0.22(0.09-0.54)$ & 0.002 & $0.85(0.41-1.76)$ & 0.641 \\
\hline \multirow[t]{2}{*}{ Disclosure } & Non-household & 74.8 & - & - & - & - \\
\hline & Household & 64.2 & $0.86(0.69-1.06)$ & 0.148 & $0.97(0.83-1.14)$ & 0.741 \\
\hline
\end{tabular}

* Adjusted for community-level prevalence of infection with M. tuberculosis at baseline as measured in schoolchildren in 2005 and classified into two strata (high and low) in each of Zambia and South Africa, age group, sex, education, marital status, household wealth index, HIV status at the time of SOCS1, community-level HIV prevalence as measured in a prevalence survey in 2010, and community-level prevalence of stigma at baseline (at the time of SOCS1).

$\mathrm{SOCS}=$ Secondary Outcome Cohort Study; TB = tuberculosis; PR = prevalence ratio; $\mathrm{CI}=$ confidence interval; HIV = human immunodeficiency virus. 
Malawi and Columbia is most similar to our indicator set for TB patients, covering similar, but less clearly demarcated, domains across 18 indicators. ${ }^{25}$ 'Being made fun of' was the most prevalent form of TB stigma experienced, especially in Zambia. Gossip (a component of being made fun of) was documented as a concern among TB patients in Pakistan, but not in Nepal or Bangladesh. ${ }^{26,27}$ Gossip is also a strong form of HIV-related stigma. ${ }^{28}$ In South Africa, the low reported experience of social exclusion could reflect tolerance towards TB patients and historical familiarity with TB. This could also be due (at least in part) to limited space and options for managing TB patients. Despite a possible social desirability bias in the reporting of the health-setting stigma experienced, low levels of this form of stigma are consistent with low levels of obvious stigma towards TB patients in health facilities, which has also been documented among health workers in the Free State Province of South Africa. ${ }^{29}$

Internalised stigma was measured using an item that asks TB patients if they feel 'unclean or dirty because of having TB'. This translated as meaning that the patient felt he was 'not pure' because of suffering from TB. Overall levels fell over time, which was encouraging. However, CIs for the effect of the household intervention on internalised stigma were wide and we did not find statistical evidence for any effect of the intervention on this outcome. It is possible that the reduction in internalised stigma reflected growing acceptance of having had TB over time as treatment progressed and was completed. In Nicaragua, multilevel and faceted interventions reduced internalised stigma over a shorter period of time. ${ }^{30}$

Disclosure to anyone outside the household was relatively high at baseline, except for South African household communities, and increased in both arms at follow-up. Over time, TB patients may have had more contact with TB services (including the household intervention) and this may have facilitated their decision to tell others. They may also have felt less ill and more able to share their diagnosis, and this could have been supported by household counsellors. Disclosure has a complex relationship with stigma. Although not disclosing can be an indication of it being unsafe to disclose, the act of disclosure itself can enhance the opportunity and experience of stigma.

Variations at community and country levels in all stigma indicators deserve attention. No strong consistent pattern could be discerned across indicators or, for example, between levels of stigma and disclosure. The open/closed (homogeneous/heterogeneous) features of communities may have influenced the imbalance at baseline across study arms (there were more closed communities in the non-household counselling arm in Zambia) and the pattern of blame in less open communities in South Africa. ${ }^{31,32}$
However, this is only a partial explanation. Community variability indicates the complex and dynamic nature of stigma and demands that we pay more attention to the influence of localised stigma. This has been pointed out by others using different approaches. Specific histories can shape stigma more than specific conditions. ${ }^{33}$ Kipp et al. also highlighted the danger of population-level stigma missing what is happening with particular groups. ${ }^{34}$ Macq et al. argued the importance of local contexts, the need for multifaceted interventions, and for the adaptability of interventions over time. ${ }^{30}$ Newell et al. and Chang et al. also emphasised variability in patterns of TB stigma across countries and cultures (e.g., around causes and knowledge and health responses). 35,36 Our analysis also suggests that localised experiences of stigma are significantly different.

\section{Study limitations}

The present study also had limitations. Loss to follow-up among the cohort was high, although the characteristics of those who were or were not followed up at SOCS2 were broadly similar. Statistical power to show a difference between the study arms was relatively low due to the large betweencommunity variation in TB stigma. There was substantial baseline imbalance between the study arms for some measures of TB stigma, although our analysis attempted to adjust for this. There may also have been reporting bias, and specifically the link between the health facility and the intervention, coupled with limited health options for managing $\mathrm{TB}$, could have made it hard for TB patients to criticise TB services. Furthermore, training of research assistants focused on technical processes, and more intensive and reflexive value clarifications that are recommended for sexual behaviour, alcohol and stigma research were relatively limited. In addition, time, experience and interviewer/interviewee interpretation could have influenced the responses of household members and TB patients at SOCS2. For example, at follow-up, TB patients were reflecting on a greater length of time with TB (as opposed to baseline, when they were within 2 months of diagnosis), with most of them cured of TB and most co-infected with HIV. The selected items were not adjusted to reflect this period between survey rounds (for example, 'since we last saw you'/'in the last 12 months'), but this had the advantage that we could capture the cumulative experience of TB patients from when they were first diagnosed with $T B$, through TB treatment, and after TB treatment.

\section{CONCLUSION}

We developed a carefully considered set of TB stigma items across key TB stigma domains using a robust mixed-method approach. These items were included 
in a cohort study to measure the outcomes of a CRT in 24 communities in Zambia and South Africa. The items included in this analysis were administered twice to $1826 \mathrm{~TB}$ patients and 1235 adults living in the household of a TB patient across the communities. Our analysis suggested that improved management of $\mathrm{TB}$ at the household level did not substantially reduce TB stigma, but also showed that stigma levels varied substantially across communities and countries.

Our findings are useful for TB control programmes. At household level, isolation of TB patients, myths about TB transmission and making TB patients culpable for their illness need addressing, particularly in Zambia, and could possibly be reduced with improved TB management. Internalised stigma and the experience of being made fun of emerge as more persistent and prevalent, and they may be responsive to intervention. Experiences of social exclusion and of health-setting stigma were encouragingly low (particularly in South Africa) and reflect a degree of familiarity with and tolerance about TB. We recommend that future TB interventions should include stigma-specific interventions rather than relying on better management of $\mathrm{TB}$ alone if a goal is to reduce TB stigma. Furthermore, we believe that mixed methods and interdisciplinary enquiry are needed for a better understanding about variations in stigma levels across different settings and any influences of subgroups, localised experiences and past events.

\section{Acknowledgements}

The present study was supported by a subcontract from Johns Hopkins University, Baltimore, MD, USA, with funds provided by grant number 19790.01 from the Bill \& Melinda Gates Foundation, Seattle, WA, USA. Its contents are solely the responsibility of the authors and do not necessarily represent the official views of the Bill \& Melinda Gates Foundation.

The authors thank the Zambia Ministry of Health (Lusaka, Zambia), City of Cape Town Health Directorate (Cape Town), the Western Cape Provincial Department of Health (Cape Town), and Zambian and South African National TB Programmes and all the district health managers and health facility staff for allowing us to work in the facilities; the Community Advisory Boards and the members of the community who participated in the trial; $\mathrm{N}$ Beyers (principal investigator); the CREATE Consortium leadership for support and scientific guidance, R Chaisson (principal investigator for CREATE) and L Moulton (Co-principal investigator for the CREATE biostatistics core) and the Zambian and South African TB and HIV Reduction Study Advisory Group: M Borgdorff, D Enarson, B Chirwa, P Mwaba, Y Mulla, L Mvusi, M Poolman, I Toms and $\mathrm{K}$ Jennings.

Conflicts of interest: none declared.

\section{References}

1 Chan B T, Tsai A C, Siedner M J. HIV treatment scale-up and HIV-related stigma in sub-Saharan Africa: a longitudinal crosscountry analysis. Am J Public Health 2015; 105: 1581-1587.

2 Ayles H, Muyoyeta M, Du Toit E, et al. Effect of household and community interventions on the burden of tuberculosis in southern Africa: the ZAMSTAR community-randomised trial. Lancet 2013; 382: 1183-1194.

3 Atre S R, Kudale A M, Morankar S N, Rangan S G, Weiss M G. Cultural concepts of tuberculosis and gender among the general population without tuberculosis in rural Maharashtra, India. Trop Med Int Health 2004; 9: 1228-1238.

4 Goffman E. Stigma: notes on a spoiled identity. New York, NY, USA: Jenkins, JH \& Carpenter, 1963.

5 Karim F, Islam M A, Chowdhury A M, Johansson E, Diwan V $\mathrm{K}$. Gender differences in delays in diagnosis and treatment of tuberculosis. Health Policy Plan 2007; 22: 329-334.

6 Scambler G. Stigma and disease: changing paradigms. Lancet 1998; 352: 1054-1055.

7 Juniarti N, Evans D. A qualitative review: the stigma of tuberculosis. J Clin Nurs 2011; 20: 1961-1970.

8 Nyblade L C. Measuring HIV stigma: existing knowledge and gaps. Psychol Health Med 2006; 11: 335-345.

9 Sontag S. Illness as metaphor and AIDS and its metaphors. Basingstoke, UK: Macmillan, 2001.

10 Shanaube K, Sismanidis C, Ayles H, et al. Annual risk of tuberculous infection using different methods in communities with a high prevalence of TB and HIV in Zambia and South Africa. PLOS ONE 2009; 4: e7749.

11 Murray E J, Marais B J, Mans G, et al. A multidisciplinary method to map potential tuberculosis transmission 'hot spots' in high-burden communities. Int J Tuberc Lung Dis 2009; 13: 767-774.

12 Bond V, Nyblade L. The importance of addressing the unfolding TB-HIV stigma in high HIV prevalence settings. J Community Appl Soc Psychol 2006; 16: 452-461.

13 Nyblade L, Pande R, Mathur S, et al. Disentangling HIV and AIDS stigma in Ethiopia, Tanzania and Zambia. Washington DC, USA: International Center for Research on Women, 2003.

14 Tanzania Stigma Indicators Field Test Group, US Agency for International Development. Working Report. Measuring HIV stigma: results of a field test in Tanzania. Washington DC, USA: International Center for Research on Women, 2005.

15 Ogden J, Nyblade L, Ashburn K, et al. Common at its core: HIV-related stigma across contexts. Washington DC, USA: International Center for Research on Women, 2005.

16 Van Rie A, Sengupta S, Pungrassami P, Balthip Q, Choonuan S, Kasetjaroen Y, et al. Measuring stigma associated with tuberculosis and HIV/AIDS in southern Thailand: exploratory and confirmatory factor analyses of two new scales. Trop Med Int Health 2008; 13: 21-30.

17 Van Brakel W H. Measuring health-related stigma-a literature review. Psychol Health Med 2006; 11: 307-334.

18 Macq J, Solis A, Martinez G. Assessing the stigma of tuberculosis. Psychol Health Med 2006; 11: 346-352.

19 Courtwright A, Turner A N. Tuberculosis and stigmatization: pathways and interventions. Public Health Rep 2010; 125 (Suppl): $34-42$.

20 Jaramillo E. Tuberculosis and stigma: predictors of prejudice against people with tuberculosis. J Health Psychol 1999; 4: 7179.

21 Rood E J J, Mergenthaler C, Bakker M I, Redwood L, Mitchell M H. Using 15 DHS surveys to study epidemiological correlates of TB courtesy stigma and health-seeking behaviour. Int J Tuberc Lung Dis 2017; 21 (Suppl 1): S60-S68.

22 Jittimanee S X, Nateniyom S, Kittikraisak W, et al. Social stigma and knowledge of tuberculosis and HIV among patients with both diseases in Thailand. PLOS ONE 2009; 4: e6360.

23 Bond V, Hoddinott G, Viljoen L, Simuyaba M, Musheke M, Seeley J. Good health and moral responsibility: key concepts underlying the interpretation of treatment as prevention in South Africa and Zambia before rolling out universal HIV testing and treatment. AIDS Patient Care STDS 2016; 30: 425434. 
24 Kipp A M, Pungrassami P, Nilmanat K, et al. Sociodemographic and AIDS-related factors associated with tuberculosis stigma in southern Thailand: a quantitative, cross-sectional study of stigma among patients with $\mathrm{TB}$ and healthy community members. BMC Public Health 2011; 11: 675.

25 Somma D, Gosoniu G D, Ganapathy S, et al. Gender and sociocultural determinants of delay to diagnosis of TB in Bangladesh, India and Malawi. Int J Tuberc Lung Dis 2008; 12: 848-855.

26 Baral S C, Karki D K, Newell J N. Causes of stigma and discrimination associated with tuberculosis in Nepal: a qualitative study. BMC Public Health 2007; 7: 211.

27 Liefooghe R, Michiels N, Habib S, Moran M B, DeMuynck A. Perception and social consequences of tuberculosis: a focus group study of tuberculosis patients in Sialkot, Pakistan. Soc Sci Med 1995; 41: 1685-1692.

28 Straetemans M, Bakker M I, Mitchell E M H. Correlates of observing and willingness to report stigma towards HIV clients by (TB) health workers in Africa. Int J Tuberc Lung Dis 2017; 21(Suppl 1): S6-S18.

29 Wouters E, Rau A, Engelbrecht M, Uebel K, et al. The development and piloting of parallel scales measuring external and internal HIV and tuberculosis stigma among healthcare workers in the Free State Province, South Africa. Clin Infect Dis 2016; 62: S244-S254.

30 Macq J, Solis A, Martinez G, Martiny P. Tackling tuberculosis patients' internalized social stigma through patient centred care: an intervention study in rural Nicaragua. BMC Public Health 2008; 8: 154.

31 Macq J, Solis A, Ibarra M, Martiny P, Dujardin B. The cost of medical care and people's health-seeking behaviour before being suspected of tuberculosis in three local health systems, Nicaragua. Int J Tuberc Lung Dis 2004; 8: 1330-1336.

32 Sismanidis C, Moulton L H, Ayles H, et al. Restricted randomization of ZAMSTAR: a $2 \times 2$ factorial cluster randomized trial. Clin Trials 2008; 5: 316-327.

33 Bond V. Terrains and tuberculosis: the model applied in urgent public health settings. In: Wallman S, ed. The capability of places: methods for modelling community response to intrusion and change. London, UK: Pluto Press, 2011: pp 80-110.

34 Hatzenbuehler M L, Phelan J C, Link B G. Stigma as a fundamental cause of population health inequalities. Am J Public Health 2013; 103: 813-821.

35 Kipp A M, Pungrassami P, Stewart P W, Chongsuvivatwong V, Strauss R P, Van Rie A. Study of tuberculosis and AIDS stigma as barriers to tuberculosis treatment adherence using validated stigma scales. Int J Tuberc Lung Dis 2011; 15: 1540-1546.

36 Chan B T, Tsai A C, Siedner M J. HIV treatment scale-up and HIV-related stigma in sub-Saharan Africa: a longitudinal crosscountry analysis. Am J Public Health 2015; 105: 1581-1587.

37 Newell J N, Pande S B, Baral S C, Bam D S, Malla P. Control of tuberculosis in an urban setting in Nepal: public-private partnership. Bull World Health Organ 2004; 82: 92-98. 


\section{APPENDIX}

\section{Household counselling intervention}

The Zambian and South African TB and HIV Reduction (ZAMSTAR) Study, a factorial cluster randomised controlled trial, was used to test two interventions that were carried out in combination or independently across 24 communities and then compared, both with each other, combined and with control sites where there were no tuberculosis (TB) interventions beyond the integration of $\mathrm{TB}$ and human immunodeficiency virus (HIV) services at government TB diagnostic health facilities. The two interventions were enhanced case-finding (which had four components: community mobilisation; open access/fast-track sputum collection points at the clinic; sputum collection points in the community; school interventions) and a household intervention. ${ }^{1}$ The household intervention is the focus of this stigma analysis because the intervention had a significant impact on TB prevalence. ${ }^{1}$

The household intervention was a strategy of combined TB-HIV activities based on World Health Organization guidelines for collaborative TB-HIV care $^{2}$ at the household level using a newly diagnosed TB patient as a gateway to a household at risk of TB and HIV. Household counsellors (nurse or lay counsellors) were trained using a standardised curriculum by the same trainers in the two countries. Anti-stigma education was not a major component of the household counselling training. However, one training session raised the issue of encountering stigmatising views among household members and asked household counsellors to brainstorm strategies for challenging any stigmatising views. These counsellors visited the household of all newly diagnosed TB patients at least thrice during the patient's treatment (treatment start, month 2 and treatment end) with the written consent of the TB patient, and provided support to the TB patient during the course of anti-tuberculosis treatment. In addition, counsellors provided TB-HIV education, TB symptom screening (using a standardised symptom checklist with referral for sputum examination for any screening-positive individuals), HIV counselling and testing, linkage to HIV care, adherence support and isoniazid preventive therapy to all consenting household members. Household members provided written informed consent to participate in the intervention. Households did not receive any incentives to be included in the intervention, except for visits by counsellors and the support and services that they offered. Household counsellors actively supported TB staff at government health facilities when they were not in the field visiting clients. Both unpublished qualitative ZAMSTAR research exploring the role of household counselling and published ethnographic research in Zambia documented household counsel- lors providing emotional support and detailed information on TB transmission when TB patients shared experiences of TB stigma during household counselling visits (Bond V \& M'lewa S. Preliminary analysis of household counselling evaluation in 3 Zambian communities in 2008. Personal communication, May 2017). ${ }^{3}$ Due to a combination of better TB management and the potential role of household counsellors in helping manage stigma, the household intervention could impact some aspects of stigma.

As health systems in Zambia and South Africa are different, interventions were applied as appropriate for the country situation. For example, as in Zambia TB smear microscopy is performed at on-site laboratories, additional microscopists were provided to cope with increased demand; in South Africa, on the other hand, as all sputum samples are sent to the centralised TB testing laboratories of the National Health Laboratory Service (NHLS), the system of recording and reporting of samples and results in the intervention clinics was strengthened.

\section{Development and reduction of TB stigma items}

To develop the TB stigma items, Bond and Hargreaves drew on a mixed-method approach: ${ }^{4}$ a body of qualitative data, a literature review, the discussions and outputs of an International Consortium for Research and Action Against health-related Stigma (ICRAAS) and the development of HIV stigma indicators. The TB stigma measurement field was more unusual and experimental.

Qualitative data included research in Zambia and South Africa that Bond had been directly involved with since 2001. In a multi-country study on HIV stigma (2001-2003) in Zambia, Tanzania and Ethiopia, ${ }^{5}$ the Zambian component included a particular focus on TB stigma. 6,7 This interest in TB stigma was sustained through the collaborative health-related stigma considerations of ICRAAS and Bond's and Weiss's particular interest in TB stigma within this group. ${ }^{8,9}$ At the beginning of ZAMSTAR, qualitative data were collected using a 'broad brush' survey approach in all 24 communities, ${ }^{8}$ as well as baseline intensive data in more limited communities, from 2005 to 2006. Ethnographic fieldwork in two communities (one Zambian, one South African) from 2006 to 2007 presented another opportunity for understanding TB stigma. 3,10 Some key areas to emerge out of this body of work was the usefulness of conceptualising stigma around causes, forms and consequences and the ability of community members and TB patients to see links between all three, ${ }^{5}$ the entanglement of TB with HIV stigma in areas with high HIV prevalence, ${ }^{7}$ the powerful harm caused by gossip, ${ }^{5}$ the overlap of TB stigma with cultural infractions, ${ }^{11}$ the specificity of $\mathrm{TB}$ transmission fears, ${ }^{7}$ and the differences in stigma and moral community across different communities and settings 


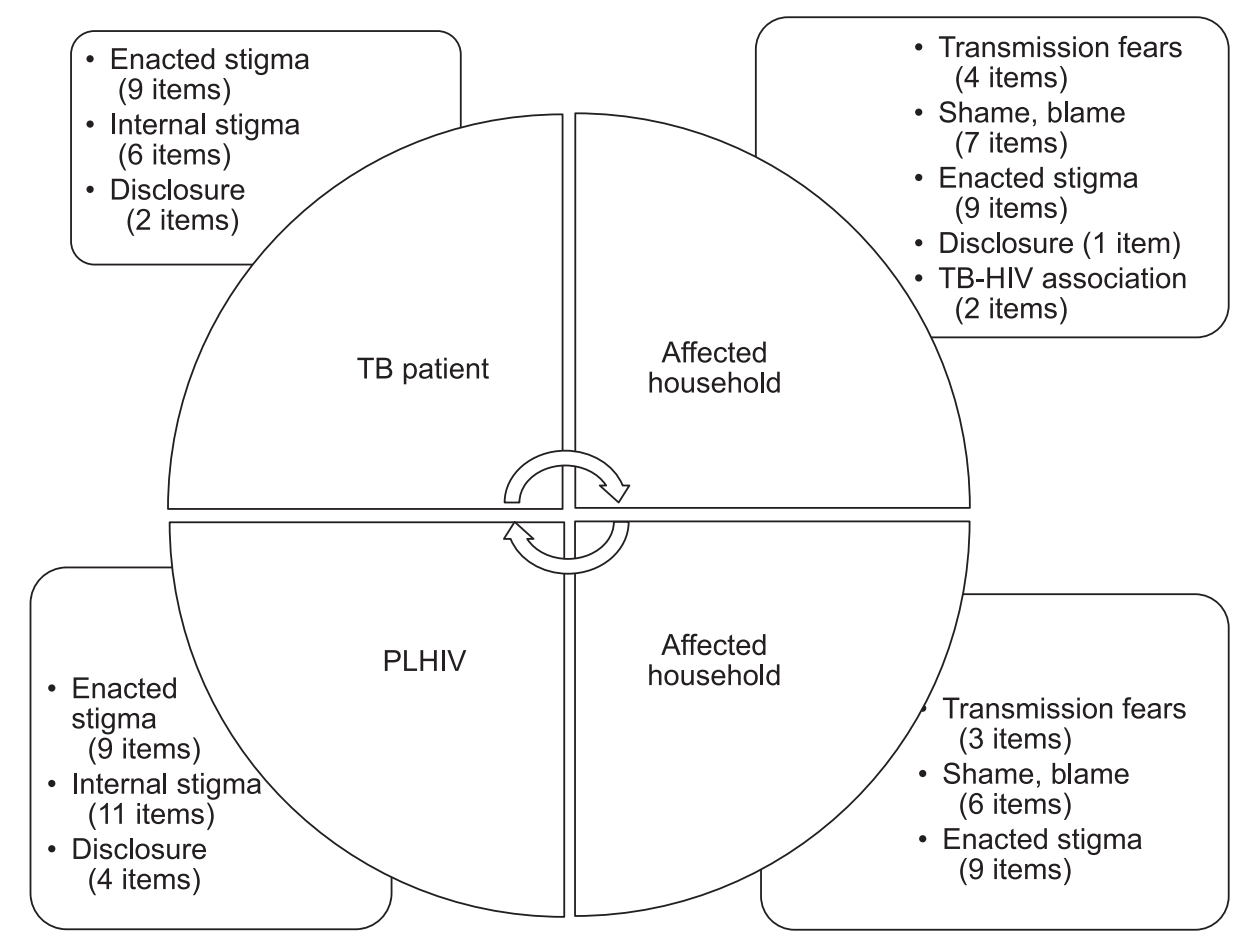

Figure A.1 Parallel domains of TB and HIV stigma. TB = tuberculosis; HIV = human immunodeficiency virus; PLHIV = people living with HIV.

(e.g., urban/rural, Zambia/South Africa). ${ }^{8}$ Table A.1 lists the initial full set of $40 \mathrm{~TB}$ stigma items and includes some examples of qualitative data insights into domains and items (Table A.1).

Bond also decided to include parallel measures for HIV stigma where feasible and appropriate, these being questions aimed at the same manifestations of stigma with the same wording but asking participants to relate these to either TB or to HIV (Figure A.1). An additional 42 items specific to HIV stigma (often parallel with TB items) were included to be administered to people living with HIV (PLHIV) and household members. This is shown in Figure A.1, with the full set of TB items listed in Table A.1. Any

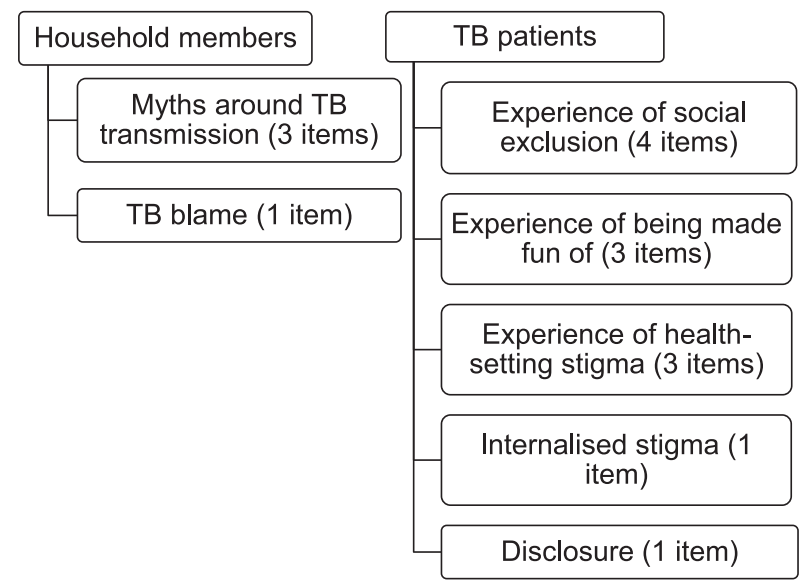

Figure A.2 Reduced TB item set (see also Table 1 in the main article). $\mathrm{TB}=$ tuberculosis. items that were newly developed (mostly TB stigma items) were piloted and reviewed by trained research assistants in English and vernacular languages (Nyanja, Bemba and Tonga in Zambia and Xhosa and Afrikaans in South Africa). All items were translated and back-translated. All the items were included in the first and second round of the Secondary Outcome Cohort Study (SOCS1 and SOCS2).

\section{Reducing the items to a favoured set}

Some examples of which TB items were excluded and why are given in Table A.1. As described in the main article, given the small number of items within each domain, and given the strong a priori theoretical reasoning for the domains listed, we did not undertake multifactorial analysis but rather used a simple approach to condensing information on multiple items within domains. This has the strong advantage of drawing heavily on previous qualitative research and making final indicators used in the analysis simple to understand. A formal scale development approach was not appropriate given the form of the data we collected in this study (Figure A.2).

To date, these TB items have also been used in South Africa both by the PLHIV Stigma Index Group and by a recent doctoral secondary data analysis at the University of Stellenbosch, Tygerberg, South Africa (Lopes C S C, Burger C \& Burger R. Investigating the health seeking behaviours of persons 
Table A.1 Full set of 40 TB items included in SOCS1 and SOCS2

\begin{tabular}{|c|c|c|c|c|}
\hline $\begin{array}{l}\text { Population } \\
\text { group }\end{array}$ & Domains & Items & Examples of qualitative data, 2005 & $\begin{array}{l}\text { Reasons for retaining/dropping } \\
\text { item }\end{array}$ \\
\hline \multicolumn{5}{|c|}{$\begin{array}{c}\text { Household members of TB patients } \\
\text { Transmission myths }\end{array}$} \\
\hline & 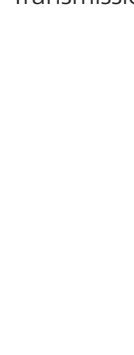 & $\begin{array}{l}\text { You can catch TB if you touch a } \\
\text { patient who is diagnosed as } \\
\text { having TB } \\
\text { You can catch TB by sharing eating } \\
\text { utensils with someone who has } \\
\text { TB } \\
\text { You can catch TB from having sex } \\
\text { with someone who has TB } \\
\text { TB patients should be isolated from } \\
\text { others in the community }\end{array}$ & $\begin{array}{l}\text { 'Some family members... do not } \\
\text { wash the TB patient for fear of } \\
\text { being infected' (community } \\
\text { members, Z12) } \\
\text { 'Households do not let TB patients } \\
\text { mix their plates and cups with } \\
\text { everyone else' (man, Z13) } \\
\text { 'My friends started asking me how } \\
\text { it feels to have sex with a woman } \\
\text { who lost her husband' (man TB } \\
\text { patient, Z15) }\end{array}$ & $\begin{array}{l}\text { Baseline agree frequencies } \\
\text { relatively high (especially in } \\
\text { Zambia) for sex and utensil fears. } \\
\text { Sex transmission fear links to } \\
\text { sexual infractions around contact } \\
\text { with a woman who has aborted } \\
\text { or been widowed. Touch and } \\
\text { isolation lower; retained touch } \\
\text { because grouped better }\end{array}$ \\
\hline & Shame a & blame & & \\
\hline & & $\begin{array}{l}\text { It is women who spread TB in our } \\
\text { communities } \\
\text { It is men who spread TB in our } \\
\text { communities } \\
\text { It is outsiders who spread TB in our } \\
\text { communities } \\
\text { TB is a punishment for bad } \\
\text { behaviour } \\
\text { TB patients are careless } \\
\text { TB patients are disgusting } \\
\text { TB patients are promiscuous }\end{array}$ & $\begin{array}{l}\text { 'TB patients are blamed for } \\
\text { catching TB...they are usually } \\
\text { those who liked going out at } \\
\text { night' (community members, Z2) } \\
\text { '. . . in some cases wives. . have } \\
\text { been blamed' (women, Z2) } \\
\text { '. . . most people with TB are } \\
\text { prostitutes' (women, Z10) }\end{array}$ & $\begin{array}{l}\text { Women/men/outsiders dropped: } \\
\text { prevalent but same individuals } \\
\text { agree with all three. 'Careless' } \\
\text { sometimes translated as } \\
\text { 'promiscuous'. Retained } \\
\text { 'punishment for bad behaviour'; } \\
\text { highest prevalence of last } 4 \\
\text { items, covariance fair, best } \\
\text { translation }\end{array}$ \\
\hline \multicolumn{5}{|c|}{ Enacted stigma } \\
\hline & & $\begin{array}{l}\text { Do you know/since we last saw } \\
\text { you, do you personally know } \\
\text { anyone with TB who has } \\
\text { experienced the following: } \\
\text { - Been excluded from a social } \\
\text { gathering } \\
\text { - Abandoned by spouse/partner } \\
\text { - Isolated by household } \\
\text { - Lost housing/denied housing for } \\
\text { rent } \\
\text { - Lost respect or standing in the } \\
\text { community } \\
\text { - Been teased, insulted or sworn at } \\
\text { - Been gossiped about } \\
\text { - Whose children or family have } \\
\text { been isolated/shunned } \\
\text { - Been treated worse than patients } \\
\text { with other diseases by health } \\
\text { staff }\end{array}$ & $\begin{array}{l}\text { 'People with TB. ... are blamed for } \\
\text { their sickness' (woman, Z1) } \\
\text { '. . . some TB patients have been } \\
\text { chased from their home' } \\
\text { (community members, Z2) } \\
\text { '. . . wives have been chased from } \\
\text { their matrimonial home' } \\
\text { (women, Z2) } \\
\text { '. . friends literally taunted their } \\
\text { friend saying 'You will die' (men, } \\
\text { Z3) } \\
\text { 'Her fellow pupils do not like } \\
\text { associating with her [girl with TB] } \\
\text { and she is constantly teased' } \\
\text { (community members, Z3) }\end{array}$ & $\begin{array}{l}\text { Verbal insults and gossip the most } \\
\text { prevalent. Losing respect and } \\
\text { standing in the community next } \\
\text { most prevalent. Covariance fair. } \\
\text { Complex composite question } \\
\text { with less consequential and more } \\
\text { serious grouped together, } \\
\text { making any composite marker } \\
\text { dominated by most prevalent. } \\
\text { Not as powerful as what TB } \\
\text { patients said has actually } \\
\text { happened to them. Dropped all } \\
\text { of them in preference of } \\
\text { experience of TB patients }\end{array}$ \\
\hline \multicolumn{5}{|c|}{ 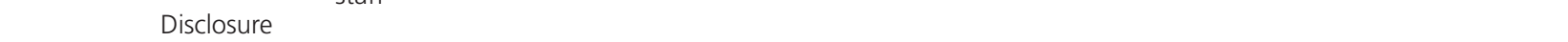 } \\
\hline & & $\begin{array}{l}\text { Have you/since we last saw you } \\
\text { have you personally come across } \\
\text { someone who has tried to hide } \\
\text { their TB diagnosis? }\end{array}$ & $\begin{array}{l}\text { 'There is stigma in the } \\
\text { community. . and that is why TB } \\
\text { patients do not like coming out } \\
\text { in the open' (community } \\
\text { members, } 215 \text { ) }\end{array}$ & $\begin{array}{l}\text { Quite prevalent, indicator of } \\
\text { disclosure but not as powerful as } \\
\text { TB patient experience so } \\
\text { dropped. }\end{array}$ \\
\hline & TB-HIV ass & $\begin{array}{l}\text { ciation } \\
\text { Do you agree or disagree with the } \\
\text { following statements: } \\
\text { - TB is curable in those living with } \\
\text { HIV } \\
\text { - All TB patients have HIVIAIDS }\end{array}$ & $\begin{array}{l}\text { 'When it comes to TB. . .because } \\
\text { they believe he/she also has HIV } \\
\text { and will die' (women, Z5) }\end{array}$ & $\begin{array}{l}\text { High agreement with first (TB is } \\
\text { curable in PLHIV) and low } \\
\text { agreement with second (all TB } \\
\text { patients have HIV). Dropped. }\end{array}$ \\
\hline
\end{tabular}


Table A.1 (continued)

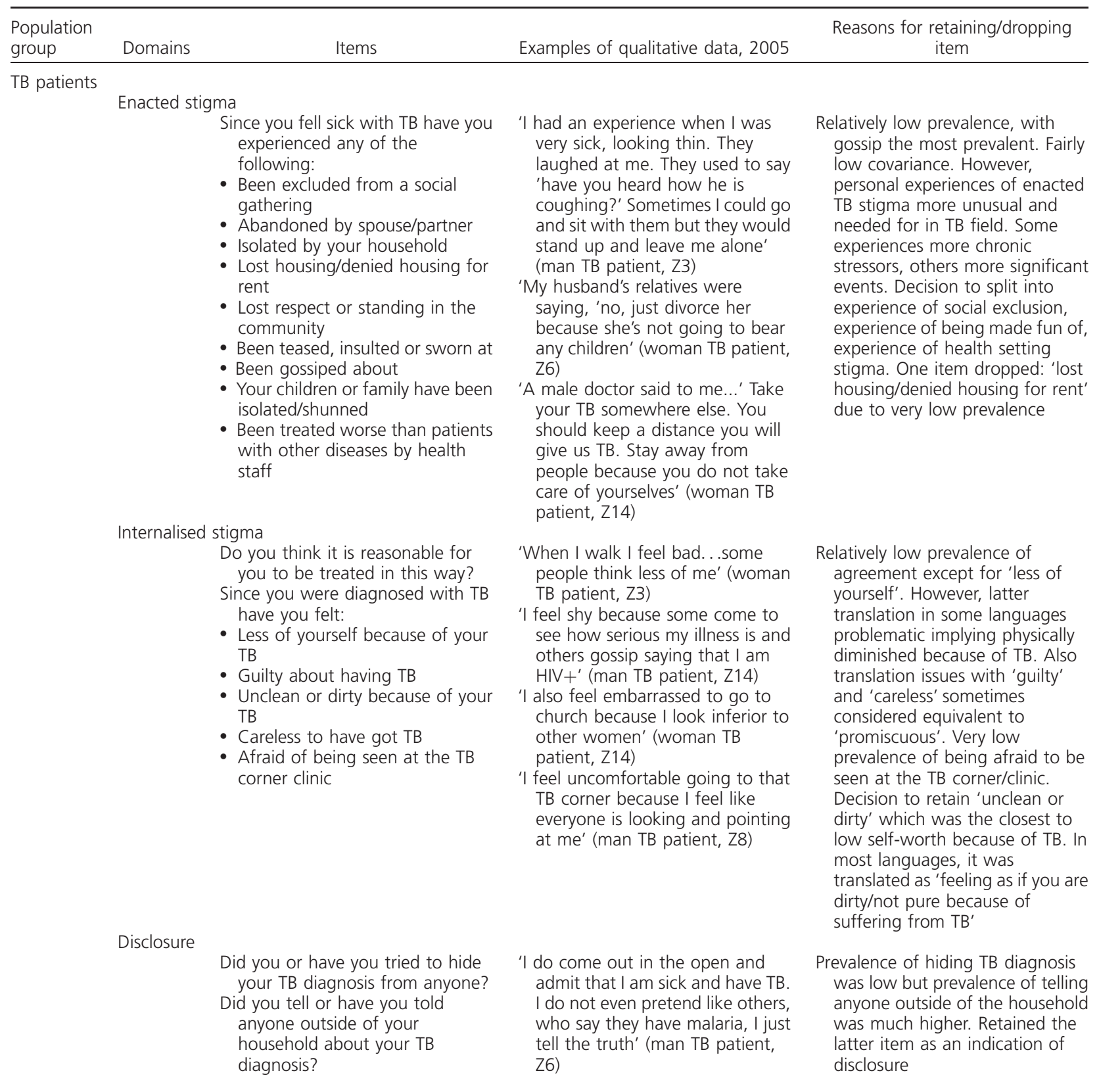

$\mathrm{TB}=$ tuberculosis; SOCS = Secondary Outcome Cohort Study; HIV = human immunodeficiency virus; += positive; AIDS=acquired immune-deficiency syndrome. 
Table A.2 Community-level values of reported stigma among household members

\begin{tabular}{|c|c|c|c|c|c|c|c|c|}
\hline \multirow[b]{2}{*}{ Country } & \multirow[b]{2}{*}{ Arm } & \multirow[b]{2}{*}{ Community } & \multicolumn{3}{|c|}{ Baseline } & \multicolumn{3}{|c|}{ SOCS2 } \\
\hline & & & $n$ & $\begin{array}{c}\text { Fears and myths } \\
n(\%)\end{array}$ & $\begin{array}{l}\text { Blame } \\
n(\%)\end{array}$ & $n$ & $\begin{array}{c}\text { Fears and myths } \\
n(\%)\end{array}$ & $\begin{array}{l}\text { Blame } \\
n(\%)\end{array}$ \\
\hline \multicolumn{9}{|l|}{ Zambia } \\
\hline & Non-household & Z1 & 239 & $127(53.1)$ & $29(12.1)$ & 73 & 51 (69.9) & $9(12.3)$ \\
\hline & & $\mathrm{Z2}$ & 216 & $147(68.1)$ & $49(22.7)$ & 96 & $37(38.5)$ & $16(16.7)$ \\
\hline & & Z5 & 97 & 74 (76.3) & $13(13.4)$ & 53 & 36 (67.9) & $5(9.4)$ \\
\hline & & Z8 & 253 & $191(75.5)$ & $82(32.4)$ & 188 & $118(62.8)$ & $50(26.6)$ \\
\hline & & Z11 & 232 & $100(43.1)$ & $56(24.1)$ & 124 & $36(29.0$ & $31(25.0)$ \\
\hline & & Z12 & 227 & $72(31.7)$ & $6(2.6)$ & 120 & $3(2.5)$ & 0 \\
\hline & & Z13 & 214 & $153(71.5)$ & 67 (31.3) & 113 & $72(63.7)$ & 35 (31.0) \\
\hline & & $\mathrm{Z16}$ & 118 & $77(65.3$ & $21(17.8)$ & 67 & $32(47.8)$ & $7(10.4)$ \\
\hline & Household & Z3 & 235 & $71(30.2)$ & $17(7.2)$ & 142 & 51 (35.9) & $6(4.2)$ \\
\hline & & Z4 & 231 & $156(67.5)$ & $67(29.0)$ & 77 & $36(46.8)$ & $17(22.1)$ \\
\hline & & Z6 & 184 & $60(32.6))$ & $1(0.5)$ & 64 & $16(25.0)$ & 0 \\
\hline & & $\mathrm{Z7}$ & 173 & $64(37.0)$ & $10(5.8)$ & 66 & $25(37.9$ & $4(6.1)$ \\
\hline & & Z9 & 147 & $64(43.5)$ & $3(2.0)$ & 73 & $0(0.0$ & $0(0.0$ \\
\hline & & Z10 & 183 & $94(51.4)$ & $30(16.4)$ & 87 & $1(1.1)$ & $7(8.0$ \\
\hline & & $\mathrm{Z} 14$ & 174 & $118(67.8)$ & 52 (29.9) & 126 & 49 (38.9) & $10(7.9)$ \\
\hline & & Z15 & 136 & $88(64.7)$ & $20(14.7)$ & 83 & $27(32.5)$ & $7(8.4)$ \\
\hline \multicolumn{9}{|c|}{ South Africa } \\
\hline & Non-household & SA2 & 201 & $53(26.4)$ & $30(14.9)$ & 57 & $2(3.5)$ & $2(3.5)$ \\
\hline & & SA4 & 214 & $59(27.6)$ & 34 (15.9) & 61 & 10 (16.4) & 7 (11.5) \\
\hline & & SA5 & 86 & $26(30.2)$ & $12(14.0)$ & 31 & 13 (41.9) & $2(6.5)$ \\
\hline & & SA7 & 224 & 91 (40.6) & 48 (21.4) & 86 & 28 (32.6) & $8(9.3)$ \\
\hline & Household & SA1 & 306 & $9(2.9)$ & $2(0.7)$ & 129 & $48(37.2)$ & $5(3.9)$ \\
\hline & & SA3 & 354 & 119 (33.6) & $23(6.5)$ & 151 & $6(4.0)$ & 0 \\
\hline & & SA6 & 105 & $1(1.0)$ & $1(1.0)$ & 47 & $2(4.3)$ & $1(2.1)$ \\
\hline & & SA8 & 273 & 86 (31.5) & $25(9.2)$ & 130 & $18(13.8)$ & $3(2.3)$ \\
\hline \multicolumn{9}{|l|}{ Zambia } \\
\hline & Non-household & & 1596 & $941(60.6)^{*}$ & $323(19.6)^{*}$ & 834 & $385(47.8)^{*}$ & $153(16.4)^{*}$ \\
\hline & Household & & 1463 & $715(49.3)^{*}$ & $200(13.2)^{\star}$ & 718 & $205(27.3)^{\star}$ & $51(7.1)^{\star}$ \\
\hline \multicolumn{9}{|c|}{ South Africa } \\
\hline & Non-household & & 725 & $229(31.2)^{*}$ & $124(16.5)^{*}$ & 235 & $53(23.6)^{*}$ & $19(7.7)^{\star}$ \\
\hline \multirow{3}{*}{ Both } & Household & & 1038 & $215(17.3)^{*}$ & $51(4.3)^{*}$ & 457 & $74(14.8)^{*}$ & $9(2.1)^{\star}$ \\
\hline & Non-housebold & & & & & & & \\
\hline & $\begin{array}{l}\text { Non-household } \\
\text { Household }\end{array}$ & & 2501 & $930(38.6)^{*}$ & $251(10.2)^{*}$ & 1175 & $279(23.1)^{*}$ & $60(5.4)^{*}$ \\
\hline
\end{tabular}

* Arithmetic mean of community-level prevalence.

SOCS $=$ Secondary Outcome Cohort Study.

coughing for more than two weeks in Western Cape South Africa, Preliminary PhD Analysis of ZAMSTAR data, University of Stellenbosch, Tygerberg, South Africa. Personal communication, 5 May 2017). The latter, which was restricted to the eight South African communities, used the same reduced set of seven TB stigma domains alongside other ZAMSTAR data to identify patterns in health-seeking behaviour in response to a cough. Their preliminary results showed that stigma inhibits the likelihood of reporting having a cough for $>2$ weeks; however, the significance of stigma tends to fall away when gender, age and race were controlled for. The authors also noted a significant variation in stigma levels across communities. The PLHIV Stigma Index has not yet shared the results of including these items in their own work.

\section{References}

1 Ayles H, Muyoyeta M, Du Toit E, et al. Effect of household and community interventions on the burden of tuberculosis in southern Africa: the ZAMSTAR community-randomised trial. Lancet 2013; 382: 1183-1194.
2 World Health Organization. WHO Policy on collaborative TB/ HIV activities: guidelines for national programmes and other stakeholders. WHO/HTM/TB/2012.1. Geneva, Switzerland: WHO, 2012.

3 Chileshe M, Bond, V. Barriers and outcomes: TB patients coinfected with HIV accessing antiretroviral therapy in Rural Zambia. AIDS Care 2010; 22: 51-59.

4 Van Brakel W H. Measuring health-related stigma-a literature review. Psychol Health Med 2006; 11: 307-334.

5 Nyblade L, Pande R, Mathur S, et al. Disentangling HIV and AIDS stigma in Ethiopia, Tanzania and Zambia. Washington DC, USA: International Center for Research on Women, 2003.

6 Bond V, Chilikwela L, Kafuma T, Nyblade L. Kanayaka-the light is on: understanding HIV/AIDS related stigma and discrimination in Zambia. Working Report. Lusaka, Zambia: Associated Press, 2003.

7 Bond V, Nyblade L. The importance of addressing the unfolding TB-HIV stigma in high HIV prevalence settings. J Community Appl Soc Psychol 2006; 16: 452-461.

8 Bond V. Terrains and tuberculosis: the model applied in urgent public health settings. In: Wallman S, ed. The capability of places: methods for modelling community response to intrusion and change. London, UK: Pluto Press, 2011: pp 80-110.

9 Weiss M. Perceptions of gender and tuberculosis in a south Indian urban community. Indian J Tuberc 2008; 55: 9-14.

10 Bond V, Chileshe M, Sullivan C, Magazi B. The converging impact of tuberculosis, HIV/AIDS and food insecurity in Zambia and South Africa. Final Working Report. Renewal 
Programme. Washington DC, USA: International Food Policy Research Institute, 2009. http://www.ifpri.org/publication/ converging-impact-tuberculosis-hivaids-and-food-insecurityzambia-and-south-africa Accessed August 2017.
11 Mogenson H. AIDS is a kind of Kahungo that kills. The challenge of using local narratives when exploring AIDS among the Tonga of Southern Zambia. Copenhagen, Denmark: Scandinavian University Press, 1995. 
CONTEXT: Communautés de l'essai randomisé en grappes (CRT) du Zambian and South African TB and HIV Reduction (ZAMSTAR), 2006-2009.

O В JECTIFS : Elaborer des items de la stigmatisation visà-vis de la tuberculose (TB) et évaluer leurs modifications en réponse à une intervention à domicile qui visait à réduire la transmission et la prévalence de la TB mais qui n'a pas été conçue pour réduire la stigmatisation.

SCHÉMA : Stigmatisation vis-à-vis de la TB a été mesurée au départ et 18 mois plus tard parmi 1826 patients TB récemment diagnostiqués et 1235 membres adultes de leurs foyers dans 24 communautés ; 12 sur 24 communautés ont été tirées au sort pour bénéficier de l'intervention à domicile. Nous avons estimé l'impact de l'intervention à domicile sur la stigmatisation TB grâce à des méthodes d'analyse de CRT standard.

RÉ SUltats : Parmi les membres des foyers, la prévalence du blâme et des croyances relatives aux mythes de transmission a chuté dans les deux bras de l'étude au fil du temps : les ratios de prévalence ajustés (aPR) comparant le bras intervention à domicile avec le bras non-intervention à domicile ont été de 0,61 (IC95\% $0,26-1,44)$ et de 0,77 (IC95\% $0,48-1,25$ ) respectivement lors du suivi après 18 mois. Parmi les patients $T B$, au départ, un faible pourcentage a expérimenté une exclusion sociale et un accueil médiocre par le personnel de santé ; un pourcentage relativement élevé a déclaré avoir été "moqué ", avec peu d'évolution dans le temps. La divulgation du statut TB a augmenté avec le temps dans les deux bras de l'étude. La stigmatisation internalisée a été moins prévalente dans le bras intervention à domicile à la fois au départ et lors du suivi, avec un aPR de 0,85 (IC95\% $0,41-1,76)$. La variabilité des niveaux de stigmatisation entre pays et à travers les communautés a été importante. CONCLUSION : Des items solides de stigmatisation TB ont été élaborés. La stigmatisation TB n'a pas été significativement réduite par l'intervention à domicile, bien que les intervalles de confiance des effets estimés de l'intervention aient été larges. Nous suggérons que des interventions spécifiques de la stigmatisation sont requises afin d'affronter efficacement la stigmatisation vis-à-vis de la TB.
MARCO DEREFERENCIA: Las comunidades en Zambia y Suráfrica que participaron en un ensayo clínico aleatorizado por conglomerados (CRT), cuyo objetivo era disminuir la TB y la infección por el VIH (ZAMSTAR), realizado del 2006 al 2009.

O в JETIV OS: Definir los elementos de la estigmatización que se asocia con la tuberculosis (TB) y analizar en qué medida se modificaron en respuesta a una intervención domiciliaria encaminada a disminuir la transmisión de la TB y su prevalencia, pero que no se había diseñado con el objeto de reducir los estigmas.

MÉTODO: Se midió la estigmatización relacionada con la TB al comienzo del estudio y 18 meses más tarde en 1826 pacientes con diagnóstico reciente de TB y 1235 adultos miembros de su familia en 24 comunidades; se escogieron de manera aleatoria 12 de las 24 comunidades para participar en la intervención domiciliaria. Se estimó el efecto de la intervención sobre los estigmas por TB mediante métodos corrientes de análisis de los ensayos aleatorizados.

RESULTADOS: La prevalencia de culpa y la creencia en los mitos sobre la transmisión disminuyeron en ambos grupos del estudio con el transcurso del tiempo, a saber: después de 18 meses de seguimiento la tasa de prevalencia ajustada (aPR) en el grupo que participó en la intervención fue 0,61 (IC95\% $0,26-1,44)$ comparada con 0,77 en el grupo que no participó (IC95\% 0,48-1,25). Al comienzo del estudio, un bajo porcentaje de los pacientes con TB percibía exclusión social y un tratamiento inadecuado por parte del personal de salud y un porcentaje relativamente alto refería 'sentirse burlado'; la modificación fue mínima con el transcurso del tiempo. La revelación de la situación con respecto a la TB aumentó con el tiempo en ambos grupos del estudio. Los estigmas percibidos fueron menos frecuentes en el grupo que participó en la intervención, al comienzo y también durante el seguimiento, con una aPR de 0,85 (IC95\% 0,41-1,76). Se observó una amplia variabilidad en el grado de estigmatización en los diferentes países y las diversas comunidades.

CONCLUSIÓN: Se formularon elementos sólidos sobre la estigmatización relacionada con la TB. La intervención en los hogares no disminuyó de manera significativa los estigmas, pese a que los IC de los efectos de la intervención fueron amplios. Se propone que con el fin de responder de manera eficaz a la estigmatización generada por la TB es necesario diseñar intervenciones que aborden de manera específica los estigmas. 